\title{
Germanic Loyalty in Nineteenth-Century Historical Studies: A Multi-Layered Virtue
}

\section{Lealdade germânica nos estudos históricos do século XIX: uma virtude de múltiplas camadas}

\author{
Herman Paul \\ http://orcid.org/0000-0002-9365-6329 (D)
}

\section{ABSTRACT}

This article seeks to advance historians' understanding of epistemic virtues in the history of historiography. Drawing on a nineteenth-century case study, it argues that virtues were often multi-layered in the sense of being charged with multiple meanings. Loyalty (Treue) is a case in point: it was, to some extent, an epistemic virtue, but simultaneously also a political virtue with conservative overtones. Loyalty served as a key concept in an idealized image that nationalistic historians and literary scholars held of the ancient Germans. Moreover, as a civic virtue, loyalty was bound up with social codes that obliged students to be loyal to their teachers - which could lead to frictions if these teachers were associated with all too pronounced views of the discipline. On this basis, the article concludes that the phrase "epistemic virtues" should be used with caution. The adjective denotes an epistemic layer of meaning which can be distinguished but never separated from social, moral, and political layers of meaning.

\section{KEYWORDS}

Epistemic virtues; German historiography; Leopold von Ranke

\section{RESUMO}

Este artigo busca promover a compreensão dos historiadores sobre as virtudes epistêmicas na História da Historiografia. Refletindo sobre um estudo de caso do século XIX, o artigo argumenta que as virtudes frequentemente possuíam múltiplas camadas, no sentido de serem carregadas com múltiplos significados. A lealdade (Treue) é um caso em questão: ela era, em certa medida, uma virtude epistêmica, mas simultaneamente também uma virtude política com conotações conservadoras. A lealdade servia como um conceito-chave em uma imagem idealizada que historiadores nacionalistas e estudiosos da literatura mantinham dos antigos germânicos. Além disso, sendo uma virtude cívica, a lealdade estava ligada a códigos sociais que obrigavam os estudantes a serem leais com seus professores - o que poderia levar a atritos se esses professores fossem associados com as visões demasiadamente pronunciadas da disciplina. Nesse sentido, o artigo conclui que a expressão "virtudes epistêmicas" deve ser usada com cautela. O adjetivo denota uma camada epistêmica de significado, que pode ser distinguida, mas jamais separada das camadas de significado sociais, morais e políticas.

\section{PALAVRAS-CHAVE}

Virtudes epistêmicas; Historiografia alemã; Leopold von Ranke 


\section{Introduction}

As Steven Shapin has demonstrated in his well-known study of seventeenth-century English gentleman scholars, the reliability of scientific experiments in early modern England was evaluated mainly in the light of the scholar's social reputation. Gentlemanly identity, expressed in virtues like modesty, impartiality and self-control, functioned as a guarantee of scientific quality. On the one hand, this explains why early modern scholars went out of their way to present themselves as immune to temptations of passion, honor, and money: a gentleman was expected to be above such passions and interests. On the other hand, it explains why the reliability of experiments seemed beyond dispute as long as they were buttressed by solid reputations. Thus, in 1692, John Warr could say about Robert Boyle, "What comes forth in the name of Mr. Boyle, and is genuinely his, needs no farther recommendation. His ipse dixit is sufficient" (SHAPIN 1994, p. 191-192).

Would a similar argument, mutatis mutandis, apply to nineteenth-century historians? As recent research has made clear, nineteenth-century historians reflected at length on the virtues required of a scholar. Almost without exception, they placed these virtues at the heart of their profession. Much of what nineteenth-century textbook authors like Ernst Bernheim codified as "historical method" consisted of virtues like accuracy, precision, and impartiality (PAUL 2011). Kasper Risbjerg Eskildsen infers from this that the main function of virtues was to warrant the reliability of historical knowledge. Nineteenth-century historians varied on an early modern theme by presenting virtue as the hallmark of "the credibility of the historical discipline" (ESKILDSEN 2013, p. 20). This explains why Eskildsen consistently describes the virtues recommended by nineteenth-century historians as epistemic virtues - dispositions or character traits necessary for achieving epistemic goals like knowledge and understanding of reality. 
But how much epistemic weight did nineteenth-century historians attach to their virtue language? Is it true that virtues were principally or even exclusively aimed at the acquisition of reliable historical knowledge? Take the obituaries written in 1886 and 1887 for Georg Waitz, the German historian who as a professor in Göttingen had initiated hundreds of young men into the historical craft and as chairman of the Monumenta Germaniae Historica had been an influential figure in German historical studies (MUHLACK 2005; BENSON; WEBER 1995; BÖCKENFÖRDE 1961, p. 99-134). A common feature in many of these obituaries is that they not only portrayed Waitz in terms of "criticism," "precision," and "penetration" (WAITZ 1867, p. 4) - virtues directly connected with the epistemic ambitions of historical studies - but also praised him for the loyalty (Treue) which he had displayed as a father, friend, citizen, and historian:

It is precisely loyalty which we would like to emphasize as the essential trait of his character. He was loyal and unswerving in his endeavor to investigate the pure historical truth, loyal as a husband and father, loyal as a teacher. It was the same loyalty that informed his political thought and sensibility[. . . ] Finally, he was loyal as a friend of his friends, of his former students; he remained in touch with almost all of them. (ERMISCH 1886, p. 269)

It is possible, of course, that this loyalty did not really touch on the heart of the matter. Perhaps the loyalty attributed to Waitz was like the frisson felt by the chemist Friedrich Wöhler when he walked through the Alps or the hospitality with which the physicist Wilhelm Weber used to receive his family in his beautiful garden in the summer - biographical trivia which found their way into obituaries because of their human interest, but without any relation whatsoever to the hypotheses, theories, and discoveries that were discussed at much greater length in Wöhler's and Weber's obituaries (PAUL 2017). However, the quotation above suggests that Treue was considerably less trivial and had to do both with knowledge acquisition and with collegiality and public responsibility. If this assumption 
is correct, then to what extent does the adjective "epistemic" adequately capture the meanings and connotations that loyalty had in nineteenth-century German historical studies?

In this article I will explore what Waitz's students meant when they characterized their deceased teacher as "loyal." I will argue that loyalty played a role in the "endeavor to investigate the pure historical truth," but also had a conservative political connotation and functioned as a key concept in an idealized image that nationalistic historians and literary scholars held of the ancient Germans. Moreover, as a civic virtue, loyalty was bound up with social codes that obliged students to be loyal to their teachers - which could lead to frictions if these teachers were associated with all too pronounced views of the discipline. On this basis I will argue, finally, that the phrase "epistemic virtues" should be used with caution. The adjective denotes an epistemic layer of meaning which can be distinguished but never separated from social, moral, and political layers of meaning.

\section{Biographical template}

The Dresden archivist Hubert Ermisch had barely returned from Berlin, where he had attended Waitz's funeral at the St. Matthew Cemetery, when he wrote a reverential obituary for the Leipziger Zeitung (Leipzig Daily). In quasi-religious terms, the piece describes how "with a quiet strength and loyal sense of duty, Waitz [had] worked on the great tasks allotted to him by Providence" (ERMISCH 1886, p. 265). According to Ermisch, this sense of duty went hand in hand with other noble character traits: accuracy, thoroughness, and a certain refinement which served to "encase a warm, deeply sensitive, and always benevolent heart" (ERMISCH 1886, p. 259). The passage just quoted on Treue as the essential trait of Waitz's character also stems from Ermisch's obituary. "As a teacher, as a scholar, so too as a human being Waitz was one of those simply true, thoroughly capable, resilient souls ..." (ERMISCH 1886, p. 259). What mattered for Ermisch, therefore, was not primarily his teacher's list of publications or Waitz's powerful influence 
on historical scholarship in Germany, but his personality or, more specifically, the virtues which had stamped his character.

A common feature of obituaries and (auto)biographies is that they illustrate the genre's conventions and the social codes of their time at least as powerfully as the specific traits of the people being described (ECHTERHÖLTER 2012). So, if Ermisch typifies Waitz as an embodiment of Treue, this tells us something about Waitz's character, but also reflects the moral universe of nineteenth-century German historians or, more broadly, the "horizon of civic values" that historians shared with other members of the educated classes (cf. PAUL 2013). In this universe of bourgeois norms and values, loyalty was a cardinal virtue. Just as spouses were supposed to be loyal to each other and soldiers swore never to abandon their comrades, so domestic servants were expected to show loyalty to their employers. Also, Treue was regarded as a mark of true friendship (FREVERT; SCHREITERER 2000; BUSCHMANN; MURR 2008). Nineteenth-century edifying literature emphasized the key importance of this virtue in genres as diverse as congratulatory letters ("Mother, accept for your loyalty / our warmest, most pious thanks") and album verses ("Practice always loyalty and reason / until your quiet grave") (STILLE 1817 , p. 17, p. 124). With reference to an idealized Germanic past (on which more below), nineteenth-century German nationalists stressed that this loyalty could not be confined to the private sphere. Social, legal, and political relations were also morally confirmed in terms of loyalty (BUSCHMANN 2009, p. 113). Finally, biographies and obituaries made it clear that this virtue translated into respect for the proper authorities, loyalty to friends and colleagues, and engagement with the weal and woe of fellow human beings (SIEGEL 2004).

Against this background it comes as no surprise that Treue often crops up in the corpus of Waitz's obituaries. Not only Ermisch, but a lot of former students portrayed Waitz as a "man of rare rectitude, loyalty, and goodness," "loyal in things great and small," imbued with "devotion to duty [Pflichttreue]," 
loyal to his teacher Leopold von Ranke, and, last but not least, "always loyal to himself" (KLUCKHOHN 1886, p. 4017; STERN 1886 , p. 540 ; CARSTENS 1887 , p. 372 ; STERN 1887, p. XXXV$x x x v i)$. On the same template, Clara Schelling, Waitz's first wife, was called a woman who had accompanied her husband "in faithful [treuer] love" on his path of life, and Waitz's second wife, Helene von Hartmann, a "loyally following wife and mother of his children" (ERMISCH 1886, p. 266). Nor was this fascination with loyalty confined to Waitz's students. Former colleague Wilhelm von Giesebrecht described the deceased as "loyal to his fatherland and to his science," while Wilhelm Wattenbach recalled the loyalty "with which [Waitz] always adhered to what he had begun" (WATTENBACH 1887, p. 3; GIESEBRECHT 1887, p. 184).

As these quotations show, loyalty was not just a virtue needed for gaining historical knowledge, but a characteristic which in a broader sense had formed Waitz into a respectable colleague and decent citizen. As Ferdinand Frensdorff would put it on a later occasion, "The virtues of his scholarship were rooted in his character and mirrored in his life" (FRENSDORFF 1914, p. 298). So, Waitz's obituaries commemorated not justhis epistemic achievements, but a man who both privately and professionally had met the high standards of an educated middle class life. A first answer to the question what "loyalty" meant for Waitz's students is therefore that they saw in this virtue a pars pro toto of a life lived well. But this is only the beginning of the story.

\section{Valhalla}

Less than 24 hours before Waitz had breathed his last in Berlin, the ninety-year-old Ranke had died elsewhere in the German capital. According to reports, Ranke had heard on his deathbed that Waitz was also seriously ill and had informed with a final effort: "So how fares the loyal Waitz?" (WATTENBACH 1887 , p. 3 ). It is not surprising that this question was often cited by Waitz's obituary writers (CARSTENS 1887, p. 374; 
STERN 1887, p. xxxvi). With all the weight of a final word, the question illustrated just how close the bond had been between Ranke and Waitz and how justifiably therefore Waitz's students could regard themselves as rightful heirs to the Rankean tradition. This was not a new idea: Waitz himself had presented his Übungen as a Göttingen continuation of Ranke's legendary Übungen in Berlin (WAITZ 1867, p. 5-6), while the 25th anniversary of Waitz's Übungen in 1874 had been celebrated as a "family party" of the Ranke family (HÖHLBAUM 1874, p. 7, p. 15). Apparently, after the almost simultaneous deaths of Ranke and Waitz, it was necessary to give new assurances that the Rankean torch would not be handed on to the school of Giesebrecht or that of Karl Wilhelm Nitzsch, but that the Waitzian school (as defined by WEBER 1984, p. 210-262) formed the inner circle of German historical studies.

Was it by chance, speculated more than one author in this connection, that Ranke and Waitz had passed away almost at the same time? Was it not a sign of deep solidarity that "the loyal Waitz" had followed his teacher into death, "just as among our forefathers the first comrade in war and companion in court [Kampf- und Bankgenosse] of the princely hero aspired to follow him to Valhalla" (SYBEL 1886)? It is striking that this image of Valhalla, introduced by Heinrich von Sybel in the Kölnische Zeitung (Cologne Daily), was taken up by various obituary writers (BIENEMANN 1886, p. 510 ; STERN 1887, p. xxxvi; FASTENRATH 1887, p. 20). There is a slight resemblance to the famous words spoken by Adolf Hitler in 1935 on the death of Paul von Hindenburg, "Dead commander, now enter Valhalla!" But it would be anachronistic to take the Nazi predilection for a "Germanicpagan conception of the hereafter" which Volker Ackermann sees illustrated in this quotation (ACKERMANN 1990, p. 116) and project it back onto Waitz's mostly Protestant colleagues and students. For them, the term "Valhalla" did not have specifically pagan connotations. Rather it belonged to a genre that was incorrigibly religious, but preferred somewhat nebulous concepts like "Providence" and "the hereafter" to 
"God" and "heaven." Even the Roman Catholic Hermann Grauert alluded in his Waitz obituary in veiled terms to "eternal rest" in "the hereafter" (GRAUERT 1887, p. 100).

More importantly, Waitz's obituary writers were fascinated by the ancient Germans, not on religious grounds, but for cultural-nationalist reasons. Their allusions to Valhalla reflect a German-nationalist worldview in which the Germans as portrayed in Tacitus' Germania functioned as forefathers and role models. Although opinions differed on the political aspirations of these Germans, so that historians disagreed on the degree of continuity existing between the Germanic tribes and the German Empire after the Franco-Prussian War (1870-1871) (KIPPER 2002, p. 252-256), almost everybody regarded the moral qualities of the ancient Germans as "part of a specifically German national stereotype" (WIWJORRA 2006, p. 110; BUSCHMANN 2008). These moral qualities, in their turn, were usually identified with typical civic virtues like honesty, chastity, purity, and loyalty. Paradigmatic of this interpretation is Gustav Freytag's Die Ahnen (The Ancestors) (1872-1880) - one of the most widely read historical novels in nineteenth-century Germany - which portrays the Germans as such exemplary citizens that the novel has been characterized as an "apotheosis of bourgeois mentality" (KIPPER 2002, p. 95). This was the front which Felix Dahn battled against when in his much-debated novel Ein Kampf um Rom (A Struggle for Rome) (1876) he went the opposite way and depicted the Germans as heroic warriors who would have raised on the shield a power politician like Otto von Bismarck (KIPPER 2002, p. 134, p. 209; cf. TITZMANN 1991).

Waitz had made an important contribution to this bourgeois idealization of the ancient Germans. Both in his lectures and in his Deutsche Verfassungsgeschichte (German Constitutional History) (1844-1878), he had described loyalty as an eminent virtue in the Germanic moral universe: "Above all loyalty is holy; it should reign in all life, of the house and the family as well as of the community and the state; the husband with 
the wife, the friend with the friend, the young man with the prince whom he serves, everybody is united with the ruler in loyalty" (WAITZ 1880, p. 46-47). This is the commonplace of germanische Treue, which was exposed as legendary by twentieth-century medievalists, but went virtually unchallenged in nineteenth-century Germany (KIENAST 1978; KROESCHELL 1995). Although Waitz was too suspicious of the classical adage historia magistra vitae to hold up this Germanic loyalty as an example to his students, they did not doubt that Waitz could identify with it and could therefore endorse the appeal of his Rostock colleague Karl Bartsch: "Let us not take second place to our forefathers!" (BARTSCH 1867, p. 24).

This context not only explains the origin of the Valhalla imagery, but also supplies a second answer to the question of what loyalty meant to Waitz's students. Waitz had confronted these students so often with germanische Treue that they responded by describing both themselves and their teacher in these terms. ${ }^{1}$ As a pupil of Waitz, Alfred Stern even believed that he formed part of a Germanic Gefolgschaft (a close-knit group of loyal followers):

The participants themselves in the Übungen [exercises] struck up lifelong friendships. Everyone felt united forever by a bond. One could say: there was born a kind of ancient Germanic Gefolgschaft in the realm of science - in pace decus, in bello praesidium [an ornament in peace, a defense in war] (STERN 1886, p. 540)

The quotation from Tacitus' Germania (13.1) with which this passage ends raises a further question. Though a standing expression often quoted as an illustration of Germanic loyalty (e.g., GIERKE 1868, p. 96; DELBRÜCK 1902, p. 29), the phrase suggests that loyalty must prove itself in conflict situations. Only when loyalties are at stake does it become clear what loyalty means. What then was the front against which the ranks had to be closed or the occasion for Stern and others to call for loyalty to Waitz's example? 


\section{Loyalty and trust}

It goes almost without saying that "Germanic loyalty" had a critical focus: explicitly or implicitly every virtue served as an alternative to one or more vices (FOOT 1978, p. 9). Hans Kloft therefore rightly points out that "Germanic loyalty" was a contrastive concept in the sense that it was critically deployed against vices which for centuries had been identified with un-German character traits ("Germanic simplicity and decency instead of Roman luxury and vice; German loyalty instead of Latin duplicity; German courage and freedom instead of Italian groveling and servility") (KLOFT 1995, p. 206). More fundamental, however, was the difference between Treue and Vertrauen, between loyalty and trust, as highlighted in recent historical research. According to Ute Frevert, especially after 1848 Treue faced competition from Vertrauen - a less hierarchical, more democratic concept that implied reciprocity and could ask for guarantees. Whereas loyalty went without saying in old-fashioned social hierarchies, trust needed to be earned and could be shattered by a single clumsy action. Frevert suggests therefore that "loyalty" had mainly conservative overtones, whereas "trust" testified to a more progressive outlook (FREVERT 2013, p. 124-125, p. 165-169).

With some difficulty, this distinction can also be found in the Waitz obituaries. Where Ermisch, a Prussia-leaning monarchist (LEHMANN 2001, p. 190), unashamedly linked loyalty to sense of duty (ERMISCH 1886, p. 267), Wilhelm Wattenbach, a moderate liberal (RODENBERG 1898, p. 442), combined the notion of loyalty with the modern, more dynamic concept of trust:

The loyal Waitz! In this word Ranke described the essence of his being. Loyal to his former teacher and fatherly friend, loyal to his fatherland and to his science, of unshakeable truthfulness, rectitude, and constancy, frank without fear of other people, and hence in all life's relationships always the one who was met with unconditional trust from all sides (WATTENBACH 1887, p. 3) 
Yet this exercise soon runs up against its limits. For despite the conservative overtones of Treue, none of Waitz's obituary writers aimed to formulate a political stance. Inasmuch as the authors engaged in controversy, their arrows were targeted not at political tendencies or social movements, but at historians who misjudged Waitz's merits or used wrong standards to assess the master. Thus Ermisch emphatically complained about "the contemptuous way in which his achievements have been judged here and there in public journals in recent days" (ERMISCH 1886, p. 268). Almost certainly this refers to Sybel's obituary in the Kölnische Zeitung, which had accused Waitz of one-sidedness (SYBEL 1886), and to an anonymous article in the Vossische Zeitung (Voss's Daily), which had blamed Waitz for having squandered his talents on matters of marginal importance (N. N. 1886). Likewise, other obituary writers defended Waitz against criticism that he had not written accessible books for an educated audience (STERN 1886, p. 540; KLUCKHOHN 1886, p. 4312). More important than the political overtones of "Germanic loyalty" was therefore its social connotation: Waitz's followers felt responsible for the reputation of their late teacher.

\section{Social reciprocity}

This concern with Waitz's posthumous reputation was rooted in a system of norms and values that broadly regulated the relations between professors and their students. Although research into these codes has been sparse for the nineteenth century, the case of Waitz shows that the privilege for students to enter the sanctuary of Waitz's study was tied up with a social obligation to show loyalty to the master. Loyalty was an expression of gratitude for the privilege of learning the tricks of the trade from Waitz and for his (often successful) efforts to get them a position at an archive or university after their doctorate. "Our gratitude," explained Ludwig Weiland, "was and is for the teaching he gave us, our veneration for the moral example he showed us" (WEILAND 1886, p. 15). The fact that 
Waitz's students vied to declare their willingness to commemorate their teacher "in constant loyalty" (STERN 1886, p. 540) therefore indicates a social reciprocity between professor and students. Education and access to the profession were repaid with thanks and honor. ${ }^{2}$

Obituaries, often explicitly presented "as a token of gratitude" (ERMISCH 1886, p. 265), were not the only genre used by Waitz's students to show "how many thanks they owed him" (GIESEBRECHT 1887, p. 292). Following nineteenthcentury academic custom (SCHNICKE 2015; TOLLEBEEK 2008, p. 186-199), they organized festive manifestations for the jubilees of their teacher. The Jubelfeier for the 25th anniversary of Waitz's historische Übungen in 1874 was the most exuberant one. ${ }^{3}$ "The festivity was prompted by the awareness of what we owed him," declared former student Konstantin Höhlbaum, thus illustrating that gratitude was not just a spontaneous feeling, but controlled by social codes (HÖHLBAUM 1874, p. 4). Another speaker, Ferdinand Frensdorff, underlined this by ending his word of thanks with a solemn pledge on behalf of all former students "that we wish always to remain loyal to the principles which we receive there [in Waitz's historische Übungen], that we will endeavor to the best of our abilities to walk in the ways shown by our teacher's teachings and writings" (HÖHLBAUM 1874, p. 12). Loyalty to Waitz was therefore seen as an appropriate response to Waitz's own loyalty. As Ermisch would put it on a later occasion, "Loyalty for loyalty! We, too, wish to preserve loyalty to him ..." (ERMISCH 1913, p. 24).

\section{Exclusive loyalty?}

What exactly did this loyalty entail? Was it loyalty to Waitz's person, as expressed in manifestations and obituaries, but also in lifelong correspondence or in a photograph of Waitz hung on a wall? Of did loyalty, as suggested by Frensdorff's pledge, also involve substantive loyalty to the historiographical program developed by Waitz? And if so, what did loyalty mean for followers who had studied elsewhere too, under historians who

2 - Frevert and Schreiterer (2000), p. 220-221 point to this element of reciprocity. On "honor" in nineteenth-century Germany, see Goldberg (2010) and Maehle (2009).

3 - For the commemorations of Waitz's seventieth birthday in 1883 and hundredth anniversary in 1913, see N. N. (1883); Ermisch (1913); Frensdorff (1914). 
held different views of the discipline from Waitz? During the 1874 Waitz-Fest, August Kluckhohn noted that the gratitude shown to Waitz did not detract from the piety which many former students owed to other teachers (HÖHLBAUM 1874, p. 6). But the fact that this declaration was needed suggests that the danger of exclusive interpretations was not imaginary. To what extent was loyalty to Waitz compatible with loyalty to other historians or other ideas about the historian's vocation?

Judging by the corpus of Waitz obituaries, loyalty to the person and loyalty to his ideas were closely connected. This is already shown by the fact that all the obituaries by former students discussed with approval their teacher's conception of his duties. This was not a feature of the genre as such: the Kölnische and Vossische Zeitung proved that not every obituary writer respected the classical adage de mortuis nil nisi bene ("say nothing but good of the dead"). Substantive assent therefore revealed as much about the author as about the conventions of the genre. One former student, Ludwig Weiland, did venture to cast doubt on Waitz's exclusive focus on historical source criticism. As an admirer of Friedrich Christoph Dahlmann and John L. Motley, both well known for their compelling prose, Weiland agreed with Sybel that Waitz had been one-sided in his devotion to historical source criticism (WEILAND 1886, p. 4; cf. WEILAND 1885, p. 6; WEILAND 1890, p. 17). On the other hand, despite his dream of higher honey, Weiland sacrificed all his research time to source editions of the kind so valued by Waitz (MÜLLER-MERTENS 1997, p. 24). Striking, too, is that students who had "moved up" in the direction of politically committed historiography in the style of Sybel and Heinrich von Treitschke did not join the choir of voices publicly commemorating Waitz. Dietrich Schäfer, for instance, did not write an obituary, though in 1910 he would dedicate his Deutsche Geschichte (German History) to the memory of both Waitz and Treitschke - a combination unthinkable 25 years earlier (SCHÄFER 1910; cf. SCHÄFER 1913 , p. 233-234). 
The fact that Waitz as a person was generally seen to be inseparable from the conception of duty which he embodied is shown by the responses that Hermann Grauert received to his Waitz obituary in the yearbook of the Roman Catholic Görres Society. Like other Catholic historians of his generation - Florenz Tourtual, August von Druffel, Hermann Cardauns and Georg Hüffer - Grauert had grown up in a milieu where the apologetic Catholic historian Johannes Janssen (on whom see TROXLER 2007) had been held in high regard (GÜNTER 1924, p. 169-170). However, frustration about their Catholic educational deficit had marked these young men more than a need to follow Janssen in his polemics with Protestant historians (DOWE 2006). Hence they had set out for Göttingen to study under Waitz, who was not an admirer of Catholic historiography (WAITZ 1846), but who according to Grauert had always displayed great friendliness and helpfulness towards the Catholic students in his audience:

Readily, therefore, people from our circles, too, have united with the other students to express their continuing veneration and gratitude for the teacher on special occasions. Thus on his 70th birthday on 9 October 1883. And we had already declared our willingness to take part in the festivities planned for the 50th anniversary of his doctorate on 18 August 1886 (GRAUERT 1887, p. 99-100).

Social reciprocity between pupil and teacher was apparently more important to Grauert than confessional difference. "The benevolence of a fatherly adviser" had to be met with "continuing veneration and gratitude" (GRAUERT 1887, p. 99).

However, in the Görres Society this homage was viewed with Argus' eyes. Waitz was one of Ranke's most important pupils and Ranke, as concerned members declared at the annual meeting of 1887 , was "the most dangerous enemy of the Catholic Church" (KLAPCZYNSKI 2013, p. 23, n. 58) - in particular on account of Die römischen Päpste in der letzten vier Jahrhunderten (The Roman Popes in the Last Four Centuries) (1834-1836), which in Catholic eyes was iconoclastic enough 
to deserve a place on the papal index (MUHLACK 2003; cf. BRECHENMACHER 1996, p. 460-475). Thanks to diplomatic efforts by chairman Georg von Hertling, a crisis in the Görres Society could be averted. Nevertheless, the affair illustrates that warm words directed at Waitz could be regarded as inappropriate for a loyal son of the Church - just as, conversely, the name of Janssen was echoed among Protestant historians as a synonym of dogmatic disloyalty to the truth (LENZ 1883, p. 238; LEHMANN 1894, p. 139; DELBRÜCK 1896, p. 417-418).

\section{Scholarly personae}

Why was it so hard to honor Waitz as a teacher without, explicitly or implicitly, endorsing his view of the historian's task? Together with Sybel, Treitschke, and Karl Lamprecht, Waitz enjoyed the dubious privilege of having seen his name grow into the symbol of a "school" or "movement" in German historical studies. Sybel and Treitschke represented the "political professor" who wanted to turn his audience into good citizens by impressing on them with patriotic enthusiasm the history of the German nation state (MUHLACK 2001; LENHARD-SCHRAMM 2014). Waitz and Lamprecht, each in his own way, were regarded as opposites of this politically committed type - Waitz with an exclusive devotion to meticulous research that was incompatible with expressive language and political commitment; Lamprecht with a cultural-historical perspective that played down the (German) nation state as a historiographical framework (PAUL 2016). Clearly, each of these models was stereotypical: Waitz's engagement with German politics was much more earnest than expressed in the clichés of historians who played off "Waitz" and "Sybel" against each other (LENHARD-SCHRAMM 2014, p. 94-103; JORDAN 1964; HAGENAH 1930). In fact, these names were no longer proper names: they had become generic names symbolizing scholarly personae or models of being a historian. Confusingly, discussions about "Waitz" were just as often related to the kind of historian that Waitz 
was considered to represent - level-headed, impersonal, critical, diligent, and objective - as to the individual behind this persona (PAUL 2018).

The fact that Waitz's person and persona were closely interwoven was noticed already in the late 1860 s by Friedrich von Bezold. As a student of Sybel in Bonn, Bezold decided to switch over to Waitz in Göttingen. By his own account, this switch was partly inspired by "a personal relationship with Waitz" (his mother had been friends with Waitz's first wife). But the personal soon turned out to be political: "That the choice then was at the same time a choice of scholarly allegiance only became clear to me in Göttingen" (BEZOLD s.a., p. 47). Almost immediately Bezold felt compelled to choose between "Sybel or Waitz," that is to say, between 'scientific" and "political" historiography as personified by Waitz and Sybel respectively (especially since Waitz in 1862 had publicly distanced himself from Sybel's politically inspired historiography) (BRECHENMACHER 2003). "Sybel or Waitz" had thus become a question of loyalty to scholarly personae: which model of the historian was the most convincing? In Bezold's memory this choice was far from non-committal: a student who ventured to speak well of Sybel in Göttingen ran the risk of being pummeled to the ground (BEZOLD s.a., p. 47).

Waitz therefore stood on two fault lines in German historical studies. As a flagbearer of the Rankean tradition he represented on the one hand the (mainly Northern German) Protestant camp, which was viewed with skepticism by traditional Catholics (above all in Southern Germany). On the other hand, as a painstaking investigator of sources, Waitz was a symbol of dedication to a scientific approach that was incompatible with Sybel's confession that he felt himself to be "4/7ths a professor and 3/7ths a politician" (VARRENTRAPP 1897, p. 128). Discussions on scholarly personae were therefore not conducted in the seclusion of the historical profession, but were influenced by lines which divided the German Empire politically, socially, and intellectually - even after the Kulturkampf (struggle 
between Church and State) in the 1880 s had formally come to an end (CLARK 2008; ALTGELD 2001; SMITH 1995). Loyalty to a historian with such a pronounced profile as Waitz thus inevitably had an element of "choosing allegiances."

Finally, this implies that the virtue language used by Waitz's pupils in their obituaries and during the 1874 jubilee was not aimed at cementing relations within German historical scholarship and thus strengthening the discipline as a whole (SCHNICKE 2015, p. 345; cf. TOLLEBEEK 2015, p. 217). That Waitz was said to have stayed loyal to his scientific vocation rather implied that the professional group also contained disloyal historians who succumbed to the temptation of public recognition or political influence. Frensdorff, too, indicated this when he solemnly pledged "to walk in the ways shown by our teacher's teachings and writings." His agreement with Waitz implied a dissociation from rival personae such as the "political professor." Loyalty to Waitz was therefore impossible without taking sides in the question as to what were the marks of a good historian.

\section{Conclusion}

In short, loyalty was a virtue with several layers of meaning. This article has shown that Treue was not just a bourgeois virtue, but also a national character trait with pronounced Germanic connotations. Germanische Treue in its turn fitted so well with the students whom Waitz had taught the Germanic origins of German law that these pupils described themselves as a Gefolgschaft - thus suggesting that loyalty to their teacher was for them a supreme duty. This article has emphasized that loyalty was an important element in the social reciprocity between teacher and pupils: historians owed loyalty to the teachers who had initiated them into the métier. In Waitz's case this loyalty involved more than lifelong exchanges of letters, incidental visits and a framed photo on the wall. Because Waitz represented a distinct scholarly persona or model of the historian's identity, loyalty to Waitz as a person was almost inextricably bound up with loyalty 
to Waitz's persona. And this was not just posthumously the case: as Bezold experienced, the decision to go and study in Göttingen already amounted to a choice of position.

What does this mean, finally, for concepts like "epistemic virtues"? For nineteenth-century German historians, Treue not only had epistemic but also political and social connotations. Loyalty, therefore, did not only serve the acquisition of historical knowledge. This might suggest that "epistemic" as an adjective is too limiting. However, as long as the adjective is not interpreted too exclusively, another conclusion is also possible. Precisely to the extent that Treue had many connotations, it is useful to specify which layer of meaning is involved - what was epistemic about Waitz's loyalty ("endeavor to investigate the pure historical truth") and what not ("loyalty as a husband and father"). Instead of a strong reading of the adjective, according to which an epistemic virtue cannot be a social or a political virtue at the same time, I therefore propose a weak reading, which recognizes that virtues may serve various purposes, but seeks to distinguish these purposes as precisely as possible (CREYGHTON et al. 2016). From this perspective, Treue was an epistemic virtue, but at the same time a nationalistic slogan, a conservative virtue, a social obligation, and a scholarly battle cry. 
ACKERMANN, Volker. Nationale Totenfeiern in Deutschland von Wilhelm I. bis Franz Josef Strauß. Eine Studie zur politischen Semiotik. Stuttgart: Klett-Cotta, 1990.

ALTGELD, Wolfgang. Religion, Denomination and Nationalism in Nineteenth-Century Germany. In: SMITH, Helmut Walser. Protestants, Catholics, and Jews in Germany, 1800-1914. Oxford: Berg, 2001, p. 49-65.

B[IENEMANN], Fr[iedrich]. Ein Gedenkblatt an Georg Waitz. Baltische Monatsschrift, v. 33, p. 510-512, 1886.

BARTSCH, Karl. Die deutsche Treue in Sage und Poesie. Vortrag gehalten am Geburtstage Seiner Königlichen Hoheit des Großhertogs von Mecklenburg-Schwerin, Friedrich Franz, am 28. Februar 1867. Leipzig: F. C. W. Vogel, 1867.

BENSON, Robert L.; WEBER, Loren J. Georg Waitz (18131886). In: DAMICO, Helen; ZAVADIL, Joseph B. Medieval Scholarship. Biographical Studies on the Formation of a Discipline, vol. 1. New York: Garland, 1995, p. 63-75.

BEZOLD, Friedrich von. Lebenserinnerungen. University archive Bonn, inv. no. Bh (s.a.).

BÖCKENFÖRDE, Ernst-Wolfgang. Die deutsche verfassungsgeschichtliche Forschung im 19. Jahrhundert. Zeitgebundene Fragestellungen und Leitbilder. Berlin: Duncker \& Humblot, 1961.

BRECHENMACHER, Thomas. Großdeutsche Geschichtsschreibung im neunzehnten Jahrhundert. Die erste Generation (1830-48). Berlin: Duncker \& Humblot, 1996. 
BRECHENMACHER, Thomas. Wie viel Gegenwart verträgt historisches Urteilen? Die Kontroverse zwischen Heinrich von Sybel und Julius Ficker über die Bewertung der Kaiserpolitik des Mittelalters (1859-1862). In: ELVERT, Jürgen; KRAUSS, Susanne. Historische Debatten und Kontroversen im 19. und 20. Jahrhundert. Stuttgart: Franz Steiner, 2003, p. 34-54.

BUSCHMANN, Nikolaus. Zwischen Leidenschaft und Disziplinierung. "Treue" als gefühlspolitischer Kampfbegriff in der neueren deutschen Geschichte. Aradia, v. 44, p. 106-120, 2009.

BUSCHMANN, Nikolaus. Die Erfindung der deutschen Treue. Vondersemantischen InnovationzurGefolgschaftsideologie. In: BUSCHMANN, Nikolaus; MURR, Karl Borromäus. Treue. Politische Loyalität und militärische Gefolgschaft in der Moderne. Göttingen: Vandenhoeck \& Ruprecht, 2008.

BUSCHMANN, Nikolaus; MURR, Karl Borromäus. Treue. Politische Loyalität und militärische Gefolgschaft in der Moderne. Göttingen: Vandenhoeck \& Ruprecht, 2008.

CARSTENS, C. Er. Geheimrath Professor Dr. G. Waitz. Zeitschrift der Gesellschaft für Schleswig-HolsteinLauenburgische Geschichte, v. 17, p. 366-374, 1887.

CLARK, Christopher. Religion and Confessional Conflict. In: RETALLACK, James, Imperial Germany 1871-1918. Oxford: Oxford University Press, 2008, p. 83-105.

CREYGHTON, Camille et al. Virtue Language in Historical Scholarship: The Cases of Georg Waitz, Gabriel Monod and Henri Pirenne. History of European Ideas, v. 42, p. 924936, 2016.

DELBRÜCK, Hans. Ueber den Ursprung des Siebenjährigen Krieges (Nachtrag). Preußische Jahrbücher, v. 86, p. 416-427, 1896. 
DELBRÜCK, Hans. Geschichte der Kriegskunst im Rahmen der politischen Geschichte, vol. 2. Berlin: Georg Stilke, 1902.

DOWE, Christoph. Auch Bildungsbürger. Katholische Studierende und Akademiker im Kaiserreich. Göttingen: Vandenhoeck \& Ruprecht, 2006.

ECHTERHÖLTER, Anna. Schattengefechte. Genealogische Praktiken in Nachrufen auf Naturwissenschaftler (17101860). Göttingen: Wallstein, 2012.

[ERMISCH], [Hubert]. Georg Waitz † 24. Mai 1886. Wissenschaftliche Beilage der Leipziger Zeitung (1886), p. 265-269.

[ERMISCH], [Hubert]. Zur Erinnerung an Georg Waitz. Dresden: C. Heinrich, 1913.

ESKILDSEN, Kasper Risbjerg. Inventing the Archive. Testimony and Virtue in Modern Historiography. History of the Human Sciences, v. 26, n. 4, p. 8-26, 2013.

FASTENRATH, Juan. Los historiadores alemanes Leopoldo de Ranke y Jorge Waitz. Revista de ciencias históricas, v. 5, p. $16-21,1887$.

FOOT, Philippa. Virtues and Vices and Other Essays in Moral Philosophy. Berkeley, CA: University of California Press, 1978.

FRENSDORFF, Ferdinand. Zur Erinnerung an den 25. Oktober 1913. Hansische Geschichtsblätter, v. 41, p. 291-299, 1914.

FREVERT, Ute. Vertrauensfragen. Eine Obsession der Moderne. Munich: C. H. Beck, 2013. 
FREVERT, Ute; SCHREITERER, Ulrich. Treue. Ansichten des 19. Jahrhunderts. In: HETTLING, Manfred; HOFFMANN, Stefan-Ludwig. Der bürgerliche Wertehimmel. Innenansichten des 19. Jahrhunderts. Göttingen: Vandenhoeck \& Ruprecht, 2000, p. 217-256.

GIERKE, Otto. Das deutsche Genossenschaftsrecht, vol. 1. Berlin: Weidmann, 1868.

GIESEBRECHT, [Wilhelm] von. Georg Waitz. In: Sitzungsberichte der philosophisch-philologischen und historischen Classe der $k$. b. Akademie der Wissenschaften zu München. Munich: k. b. Akademie der Wissenschaften, 1887 , p. 277-293.

GIESEBRECHT, [Wilhelm] von. Georg Waitz. Worte der Erinnerung an König Ludwig II, Leopold v. Ranke und Georg Waitz. Historische Zeitschrift, v. 58, p. 181-185, 1887.

GOLDBERG, Ann. Honor, Politics, and the Law in Imperial Germany, 1871-1914. Cambridge: Cambridge University Press, 2010.

GRAUERT, Herm[ann]. Georg Waitz. Historisches Jahrbuch, v. 8, p. 48-100, 1887.

GÜNTER, Heinrich. Hermann v. Grauert t. Historisches Jahrbuch, v. 44, p. 169-196, 1924.

HAGENAH, Hermann. Georg Waitz als Politiker. Veröffentlichungen der Schleswig-Holsteinischen Universitätsgesellschaft, v. 31, p. 134-217, 1930.

[HÖHLBAUM], [Konstantin]. Die Jubelfeier der historischen Übungen zu Göttingen am 1. August 1874. Bericht des Fest-Comités. Göttingen: private printing, 1874. 
JORDAN, Karl. Georg Waitz als Professor in Kiel. In: CLASSEN, Peter; SCHEIBERT, Peter. Festschrift Percy Ernst Schramm zu seinem siebzigsten Geburtstag von Schülern und Freunden zugeeignet, vol. 2 . Wiesbaden: Franz Steiner, 1964, p. 90-104.

$\mathrm{K}[\mathrm{LUCKHOHN}], \quad \mathrm{A}$ [ugust]. Georg Waitz. Allgemeine Zeitung (1886), p. 4017-4018, p. 4041-4042, p. 43134314, p. 4385-4386.

KIENAST, Walther. Germanische Treue und "Königsheil." Historische Zeitschrift, v. 227, p. 265-324, 1978.

KIPPER, Rainer. Der Germanenmythos im Deutschen Kaiserreich. Formen und Funktionen historischer Selbstthematisierung. Göttingen: Vandenhoeck \& Ruprecht, 2002.

KLAPCZYNSKI, Gregor. Katholischer Historismus? Zum historischen Denken in der deutschsprachigen Kirchengeschichte um 1900. Heinrich Schrörs, Albert Ehrhard, Joseph Schnitzer. Stuttgart: W. Kohlhammer, 2013.

KLOFT, Hans. Die Idee einer deutschen Nation zu Beginn der frühen Neuzeit. Überlegungen zur Germania des Tacitus und zum Arminius Ulrichs von Hutten. In: WIEGELS, Rainer; WOESLER, Winfried. Arminius und der Varusschlacht. Geschichte, Mythos, Literatur. Paderborn: Ferdinand Schönigh, 1995, p. 197-210.

KROESCHELL, Karl. Die Treue in der deutschen Rechtsgeschichte. In: KROESCHELL. Studien zum frühen und mittelalterlichen deutschen Recht. Berlin: Duncker \& Humblot, 1995, p. 157-182.

LACAPRA, Dominick. History and Criticism. Ithaca, NY: Cornell University Press, 1985.

LEHMANN, Jana. Hubert Ermisch 1850-1932. Ein Beitrag zurGeschichtedersächsischen Landesgeschichtsforschung. Cologne: Böhlau, 2001. 
LEHMANN, Max. Friedrich der Grosse und der Ursprung des Siebenjährigen Krieges. Leipzig: S. Hirzel, 1894.

LENHARD-SCHRAMM, Niklas. Konstrukteure der Nation. Geschichtsprofessoren als politische Akteure in Vormärz und Revolution 1848/49. Münster: Waxmann, 2014.

LENZ, Max. Janssen's Geschichte des deutschen Volkes. Eine analytische Kritik. Historische Zeitschrift, v. 50, p. 231-284, 1883.

MAEHLE, Andreas-Holger. Doctors, Honour and the Law. Medical Ethics in Imperial Germany. Basingstoke: Palgrave Macmillan, 2009.

MUHLACK, Ulrich. Der "politische Professor" im Deutschland des 19. Jahrhunderts. In: BURKHOLZ, Ronald; GÄRTNER, Christel; ZEHENTREITER, Ferdinand. Materialität des Geistes. Zur Sache Kultur. Im Diskurs mit Ulrich Oevermann. Weilerswist: Velbrück, 2001, p. 185-204.

MUHLACK, Ulrich. Die wissenschaftsgeschichtliche Bedeutung des Indexverfahrens gegen Rankes Papstgeschichte. In: WOLF, Hubert; BURKARD, Dominik; MUHLACK, Ulrich. Rankes "Päpste" auf dem Index. Dogma und Historie im Widerstreit. Paderborn: Ferdinand Schönigh, 2003, p. 169-201.

MUHLACK, Ulrich. Die Stellung von Georg Waitz in der deutschen Geschichtswissenschaft des 19. Jahrhunderts. In: JIROUŠEK, Bohumil; BLÜML, Josef; BLÜMLOVÁ, Dagmar. Jaroslav Goll a jeho žáci. České Budějovice: Jihočeská Univerzita, 2005, p. 165-181.

MÜLLER-MERTENS, Eckhard. Constitutiones et acta publica. Paradigmenwechsel und Gestaltungsfragen einer MonumentaReihe. In: LINDNER, Michael; MÜLLER-MERTENS, Eckhard; RADER, Olaf B. Kaiser, Reich und Region. Studien und Texte aus der Arbeit an den Constitutiones des 14. Jahrhunderts und zur Geschichte der Monumenta Germaniae Historica. Berlin: Akademie-Verlag, 1997, p. 1-59. 
N. N. Die zum 9. October an G. Waitz nach Bellagio am Comer See übersandte Adresse. Berlin: private printing, 1883.

N. N. Georg Waitz †. Vossische Zeitung (25 May 1886).

PAUL, Herman. Distance and Self-Distanciation. Intellectual Virtue and Historical Method around 1900. History and Theory, v. 50, n. 4, p. 104-116, 2011.

PAUL, Herman. "Werken zoo lang het dag is." Sjablonen van een negentiende-eeuws geleerdenleven. In: DORSMAN, L. J.; KNEGTMANS, P. J. De menselijke maat in de wetenschap. De geleerden(auto)biografie als bron voor de wetenschaps- en universiteitsgeschiedenis. Hilversum: Verloren, 2013, p. 53-73.

PAUL, Herman. The Virtues and Vices of Albert Naudé. Toward a History of Scholarly Personae. History of Humanities, v. 1, p. 327-338, 2016.

PAUL, Herman. Weber, Wöhler, and Waitz. Virtue Language in Late Nineteenth-Century Physics, Chemistry, and History. In: DONGEN, Jeroen van; PAUL, Herman. Epistemic Virtues in the Sciences and the Humanities. Cham: Springer, 2017, p. 91-107.

PAUL, Herman. The Virtues of a Good Historian in Early Imperial Germany. Georg Waitz's Contested Example. Modern Intellectual History, v. 15, p. 681-709, 2018.

RODENBERG, C. Wattenbach. In: Allgemeine Deutsche Biographie, v. 44. Leipzig: Duncker \& Humblot, 1898, p. 439-443.

SCHÄFER, D. Deutsche Geschichte, vol. 1. Jena: Gustav Fischer, 1910. 
SCHÄFER, D. Antrittsrede beim Eintritt in die königlich Preußische Akademie der Wissenschaften 30. Juni 1904. In: SCHÄFER. Aufsätze, Reden und Vorträge, vol. 2. Jena: Gustav Fischer, 1913, p. 232-241.

SCHNICKE, Falko. Rituale der Verkörperung. Seminarfeste und Jubiläen der Geschichtswissenschaft des 19. Jahrhunderts. Zeitschrift für Geschichtswissenschaft, v. 63, p. 337-358, 2015.

SHAPIN, Steven. A Social History of Truth. Civility and Science in Seventeenth-Century England. Chicago: University of Chicago Press, 1994.

SIEGEL, Eva-Maria. High Fidelity. Konfigurationen der Treue um 1900. Munich: Fink, 2004.

SMITH, Helmut Walser. German Nationalism and Religious Conflict. Culture, Ideology, Politics, 1870-1914. Princeton, NJ: Princeton University Press, 1995.

STERN, Alfred. Georg Waitz. Die Nation, v. 3, p. 538-540, 1886.

STERN, Alfred. Gedächtnisrede auf Leopold von Ranke und Georg Waitz. Jahrbuch für schweizerische Geschichte, v. 12 , p. xi-xxxvi, 1887.

STILLE, Jakob. Gratulations-Büchlein für die Jugend, ed. Jakob GLATZ, 3rd ed. Vienna: Doll, 1817.

SYBEL, Heinrich v[on]. Georg Waitz. Kölnische Zeitung (26 May 1886).

TITZMANN, Michael. Die Konzeption der "Germanen" in der deutschen Literatur des 19. Jahrhunderts. In: LINK, Jürgen; WÜLFING, Wulf. Nationale Mythen und Symbole in der zweiten Hälfte des 19. Jahrhunderts. Strukturen und Funktionen von Konzepten nationaler Identität. Stuttgart: Klett-Cotta, 1991, p. 120-145. 
TOLLEBEEK, Jo. Fredericq \& Zonen. Een antropologie van de moderne geschiedwetenschap. Amsterdam: Bert Bakker, 2008.

TOLLEBEEK, Jo. Commemorative Practices in the Humanities around 1900. Advances in Historical Studies, v. 4, p. 216-231, 2015.

TROXLER, Walter. Ein Aussenseiter der Geschichtsschreibung. Johannes Janssen 1829-1891: Studien zu Leben und Werk eines katholischen Historikers. Berlin: Pro Business, 2007.

VARRENTRAPP, Conrad. Biographische Einleitung. In: SYBEL, Heinrich von. Vorträge und Abhandlungen, ed. Conrad VARRENTRAPP. Munich: Oldenbourg, 1897, p. 1-156.

WAITZ, G. Deutsche Historiker der Gegenwart. Briefe an der Herausgeber. Allgemeine Zeitschrift für Geschichte, v. 5, p. 520-535, 1846.

WAITZ, G. Die historischen Übungen zu Göttingen. Glückwunschschreiben an Leopold von Ranke zum Tage der Feier seines fünfzigjährigen Doctorjubiläums, 20. Februar 1867. Göttingen: private printing, 1867.

WAITZ, G. Deutsche Verfassungsgeschichte, vol. 1, 3rd ed. Berlin: Weidmann, 1880.

WATTENBACH, [Wilhelm]. Gedächtnisrede auf Georg Waitz. In: WATTENBACH, [Wilhelm] Abhandlungen der Königlichen Akademie der Wissenschaften zu Berlin aus dem Jahre 1886. Berlin: K. Akadmie der Wissenschaften, 1887 , p. 1-12.

WEBER, Wolfgang. Priester der Klio. Historischsozialwissenschaftliche Studien zur Herkunft und Karriere deutscher Historiker und zur Geschichte der Geschichtswissenschaft 1800-1870. Frankfurt am Main: Peter Lang, 1984. 
WEILAND, Ludwig. Friedrich Christoph DahImann. Rede zur Feier seines hundertjährigen Geburtstages am 13. Mai 1885 im Namen der Georg-Augusts-Universität gehalten. Göttingen: Dieterich, 1885.

WEILAND, Ludwig. Georg Waitz (geb. 9. October 1813, gest. 24. Mai 1886). Rede gehalten in der öffentlichen Sitzung der K. Gesellschaft der Wissenschaften am 4. Dezember 1886. Göttingen: Dieterich, 1886.

WEILAND, Ludwig. Rede des Herrn Prof. Dr. Weiland. In: WEILAND, Ludwig. Fest-Reden bei der ErinnerungsFeier an Edward Everett, George Bancroft, Henry W. Longfellow und John L. Motley gehalten in der Aula der Georgia-Augusta, Göttingen, 4. Juli 1890. Göttingen: Dieterich, [1890], p. 14-19.

WIWJORRA, Ingo. Der Germanenmythos. Konstruktion einer Weltanschauung in der Altertumsforschung des 19. Jahrhunderts. Darmstadt: Wissenschaftliche Buchgesellschaft, 2006.

\section{ACKNOWLEDGMENT AND INFORMATION}

\section{Herman Paul ৫}

h.j.paul@hum.leidenuniv.nl

Leiden University

Netherlands

This article originally appeared in Dutch in Herman Paul, De deugden van een wetenschapper: karakter en toewijding in de geesteswetenschappen, 1850-1940 (Amsterdam: Amsterdam University Press, 2018), p. 83-99. With kind permission from Amsterdam University Press, it was translated into English by Anthony P. Runia. The research was generously supported by the Netherlands Organization for Scientific Research, while the translation costs were covered by The Young Academy (Royal Netherlands Academy of Arts and Sciences).

Portuguese title and abstract translated by Walderez Simões Costa Ramalho. 